\title{
Glucocorticoids stimulate the division of rat pancreatic islet tumour cells in tissue culture
}

\author{
G. Brons ${ }^{1}$, A.C. Newby ${ }^{3}$ and C. N. Hales ${ }^{2}$ \\ Departments of ${ }^{1}$ Surgery and ${ }^{2}$ Clinical Biochemistry, University of Cambridge, Addenbrooke's Hospital, Cambridge, and \\ ${ }^{3}$ Department of Cardiology, Welsh National School of Medicine, Cardiff, UK
}

\begin{abstract}
Summary. The effects of hormones on the growth of $\beta$ cells, obtained from an X-ray induced transplantable rat islet cell tumour, were studied in tissue culture. Cells were cultured in Dulbecco's modified medium containing $1 \%$ bovine serum albumin, which did not permit fibroblast outgrowth. Among a variety of different hormones tested, the most potent growth promoters were found to be the corticosteroids whose potency was related to their glucocorticoid activity. After 5 weeks in culture with prednisolone $(270 \mathrm{nmol} / \mathrm{l})$, all cells stained immunohistochemically for insulin, although the insulin content was decreased to $10 \%$ that of fresh cells. Growth hormone
\end{abstract}

$(10 \mu \mathrm{g} / \mathrm{ml})$ stimulated DNA replication to a small extent in the presence or absence of glucocorticoids. Insulin secretion from freshly prepared tumour cells was not stimulated by glucose but was increased two- to threefold by leucine $(20 \mathrm{mmol} / \mathrm{l})$ plus theophylline $(5 \mathrm{mmol} / 1)$. This pattern of stimulation was observed still in cells cultured for 4 weeks in prednisolonesupplemented medium.

Key words: Glucocorticoids, pancreatic islet cell tumour, $\beta$-cell replication, tissue culture.
A permanent $\beta$-cell line would be useful for the study of insulin synthesis, storage and secretion. It would also provide an opportunity to study the effects of toxic factors which might be responsible for $\beta$-cell defects. The establishment of such a line would be aided by knowledge of the factors regulating the proliferation of $\beta$ cells in vivo and in vitro. Various agents have been reported to influence the replication of $\beta$ cells from fetal, neonatal and adult tissues during short-term culture [1-6], but none of these have resulted in a rapidly proliferating cell line. In this work we have studied the initial growth requirements of transformed $\beta$ cells obtained from a transplantable tumour with the aim that they may provide the basis for establishing such a cell line.

\section{Materials and methods}

\section{Tissue culture method}

Rat insulinomas $(0.5-1 \mathrm{~g})$ propagated as described previously [7, 8] were excised under sterile conditions, teased apart in $20 \mathrm{ml}$ of medium (see below) and the cells recovered by centrifugation at $300 \mathrm{~g}$. Cells were resuspended in isotonic ammonium chloride solution $(20 \mathrm{ml})$ for $5 \mathrm{~min}$ (to eliminate erythrocytes), washed twice and resuspended in $20 \mathrm{ml}$ of medium, layered over $20 \mathrm{ml}$ of a $10 \%$ bovine serum albumin solution in medium and allowed to settle for $1 \mathrm{~h}$. Sedimented cells were washed and resuspended in $30 \mathrm{ml}$ of medium and cultured overnight at $37^{\circ} \mathrm{C}$ under $5 \% \mathrm{CO}_{2}$ in air.
The incubated cells were washed and resuspended in fresh tissue culture medium, adjusted to $1-2 \times 10^{7}$ cells $/ \mathrm{ml}$ and $20 \mu \mathrm{l}$ of this suspension was added to $200 \mu \mathrm{l}$ of tissue culture medium with or without additives in microtitre plates (Gibco Europe, Uxbridge, UK). Alternatively, $1-2 \mathrm{ml}$ of the cell suspension was placed in tissue culture bottles containing $10 \mathrm{ml}$ tissue culture medium. At the times indicated aliquots $(200 \mu \mathrm{l})$ were plated out into microtitre plates for analysis. In all cases, the medium was changed every second day by replacing the supernatant with fresh medium.

The tissue culture medium (Dulbecco's modified medium) was prepared from dried powder (Gibco) and supplemented with $\mathrm{NaHCO}_{3}(15 \mathrm{mmol} / \mathrm{l})$, Hepes/ $\mathrm{NaOH}$ (15 mmol/1), pH 7.4 (CP Laboratories, Bishop Stortford, Herts, UK), Penicillin-streptomycin (200 mg/l) (Glaxo, Evans Medical, Greenford, Middlesex, UK) and either $1 \%$ bovine serum albumin (BSA), fraction V (Sigma, Poole, UK) or $5-20 \%$ fetal calf serum (Gibco) and sterilized by filtration (Millipore, Harrow, UK). Dexamethasone, prednisolone, hydrocortisone (Merck, Sharp \& Dohme, Hoddesdon, Herts, UK), and aldosterone (Sigma) were diluted in medium. Water-insoluble hormones were dissolved in ethanol and diluted with medium so that the higher control concentration used contained $<1 \%$ ethanol. Bovine growth hormone was a gift from Dr. M. Wallis, School of Biological Sciences, University of Sussex, Falmer, Brighton, Sussex, UK, and was dissolved in $0.15 \mathrm{~mol} / 1 \mathrm{NaHCO}_{3}$ and diluted with medium.

\section{Analytical methods}

For incorporation of ${ }^{3} \mathrm{H}$-thymidine into DNA, cells in microtitre plates were exposed for $18 \mathrm{~h}$ to ${ }^{3} \mathrm{H}$-thymidine $(1 \mu \mathrm{Ci}$, spec. act. $20-30 \mathrm{Ci} / \mathrm{mmol}$, Amersham International, Bucks, UK) per microtitre well and then harvested onto glass fibre discs (Whatman Uniscience, Cambridge, UK) with a Titertek cell harvester (Flow Laboratories, 
Irvine, Scotland) allowing thorough washing with distilled water. After drying, the discs were immersed in scintillation fluid and the radioactivity was determined with a liquid scintillation spectrometer (Tri-carb, Packard Instruments, Downers Grove, Illinois, USA).

For measurement of DNA content, cell suspension $(200 \mu)$ was frozen $\left(-20^{\circ} \mathrm{C}\right)$, thawed three times and analysed by the method of Kissane and Robins [9] using calf thymus DNA (Sigma) as standard.

For measurement of insulin content, cells from $200 \mu \mathrm{l}$ of suspension were washed twice in medium and resuspended in medium $(200 \mu \mathrm{l})$ containing $0.1 \%$ Triton $\mathrm{X}-100$ (Sigma) and frozen $\left(-20^{\circ} \mathrm{C}\right)$ and thawed three times. The supernatant was assayed by the method of Hales and Randle [10] with rat insulin (Novo, Basingstoke, UK) as standard.

The secretory response of the incubated cells was determined by the static method of Sopwith et al. [8]. Two consecutive 60-min incubations were performed to establish the basal secretory rate, the cells being separated from the media each time by centrifugation. Medium containing $1 \%$ BSA and either glucose $(5.5 \mathrm{mmol} / 1$, basal $)$, glucose $(20 \mathrm{mmol} / \mathrm{l})$ or leucine $(20 \mathrm{mmol} / \mathrm{l})$ plus theophylline $(5 \mathrm{mmol} / \mathrm{l})$ as secretagogues was then introduced for $60 \mathrm{~min}$ and subsequently a further $60 \mathrm{~min}$ incubation in basal medium was carried out. The insulin content in the supernatants and final cell pellet was determined as above.

For immunohistochemical staining for insulin, tumour pieces $\left(0.5 \times 0.5 \mathrm{~cm}^{3}\right)$ were fixed in Bouin's solution (Raymond Lamb, London, UK) for $24 \mathrm{~h}$, washed in $70 \%$ ethanol and embedded in paraffin. Cells were air dried on glass slides pre-treated with $0.1 \%$ glycerol in $0.9 \% \mathrm{NaCl}$, fixed with Bouin's solution for $2 \mathrm{~h}$ and washed with $70 \%$ ethanol. Thin paraffin sections or the cell slides were stained for insulin by the immunohistochemical staining procedure of Heyderman [11], using antibody to bovine insulin raised in guinea pigs and peroxidase labelled rabbit anti-guinea pig IgG (Miles Laboratories, Slough, Bucks, UK). Both antibodies were used at a 1:100 dilution.

\section{Statistical analysis}

Results are expressed as mean \pm SEM throughout, except for Figure 1 where the results are expressed as mean $\pm \mathrm{SD}$. Paired data were evaluated for statistical significance by the Wilcoxon signed rank test. Student's t-test was used to compare unpaired data. $p<0.05$ was considered significant.

\section{Results}

\section{Immunohistochemical staining for insulin}

Immunohistochemical staining of paraffin sections of the tumour revealed that approximately $70 \%$ of the total cell mass consisted of cells containing insulin. These cells were enmeshed in a dense fibrous collagenous matrix containing numerous small blood vessels, blood cells, mononuclear cells and adipose tissue. The appearance of the tumour cells was oval and columnar in shape and organised in cords and clusters in close proximity to small blood vessels. Insulin was shown to be concentrated at the vascular pole of the cells. The tumour line was repeatedly screened for other hormones, but proved to be negative by immunohistochemical staining for glucagon, somatostatin, gastrin, pancreatic polypeptide, neurotensin, vasoactive intestinal polypeptide, and B-lipotropin (personal communications: T.E. Adrian, S. R. Bloom, I.Doniach, L.H. Rees). Less

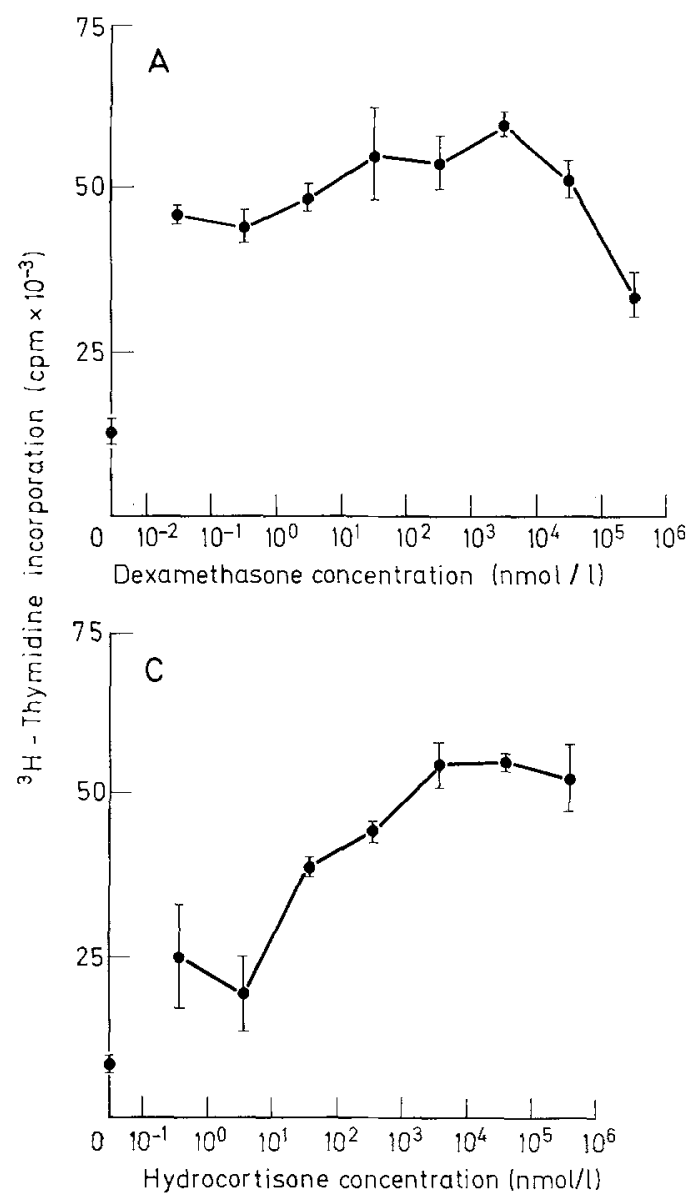

Hydrocortisone concentration (nmol/l)

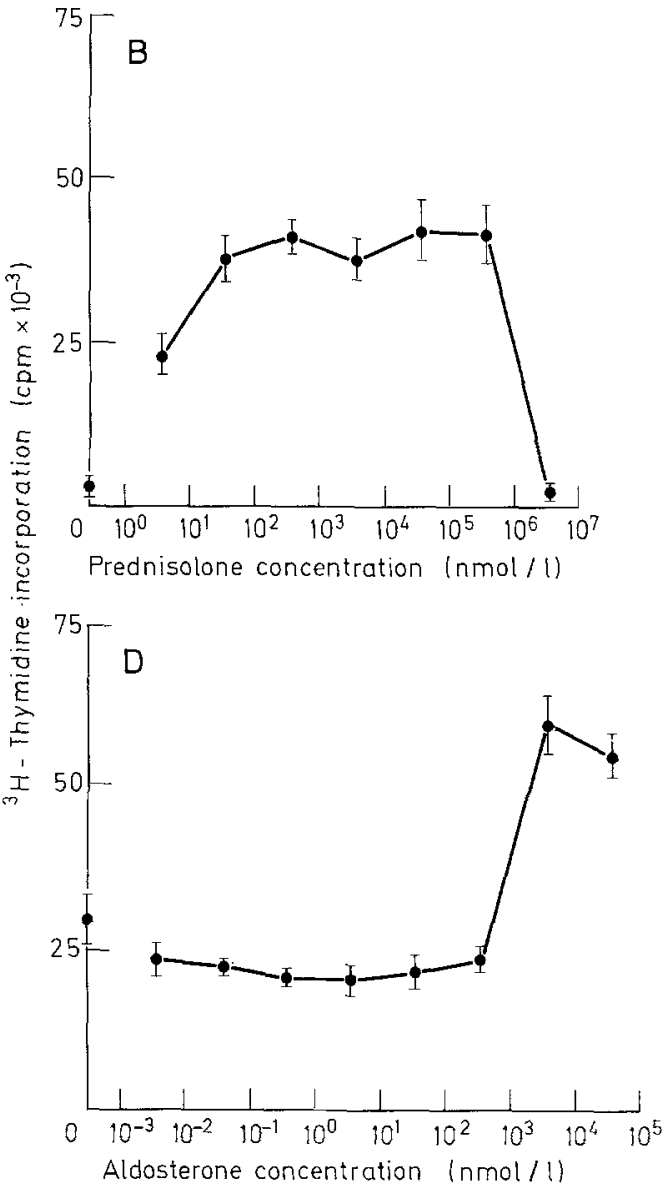

Fig. 1 A-D. Results of ${ }^{3} \mathrm{H}$-thymidine incorporation into cultured cells in response to varying concentrations of $\mathbf{A}$ dexamethasone; B prednisolone; $C$ hydrocortisone and $\mathbf{D}$ aldosterone. Tumour cells were cultured in medium containing bovine serum albumin plus hormone for 8 days. ${ }^{3} \mathrm{H}$ thymidine incorporation per culture well was measured over the last $18 \mathrm{~h}$ of culture. Values are mean \pm SD of triplicate cultures 
Table 1. Growth response of rat islet tumour cells exposed for 8 days to a maximally effective hormone concentration

\begin{tabular}{lcc}
\hline $\begin{array}{l}\text { Hormone } \\
\text { concentration } \\
\text { (nmol/1) }\end{array}$ & $\begin{array}{l}\text { Relative } \\
\text { 3H-thymidine } \\
\text { incorporation }\end{array}$ & $\begin{array}{l}\text { Number } \\
\text { of } \\
\text { observations }\end{array}$ \\
\hline Progesterone (320) & $0.73 \pm 0.04$ & 6 \\
$\beta$-Oestradiol $(370)$ & $0.73 \pm 0.04$ & 6 \\
$\beta$-Oestradiol benzoate $(2700)$ & $0.75 \pm 0.04$ & 6 \\
Testosterone $(0.0035)$ & $0.97 \pm 0.06$ & 3 \\
L-Thyroxine $(0.011)$ & $1.04 \pm 0.06$ & 3 \\
Triiodothyronine $(0.15)$ & $0.55 \pm 0.06$ & 3 \\
Dexamethasone $(0.025)$ & $3.33 \pm 0.28$ & 15 \\
Prednisolone $(270)$ & $12.35 \pm 0.9$ & 15 \\
Hydrocortisone $(270)$ & $6.0 \pm 0.41$ & 6 \\
Aldosterone $(2700)$ & $2.01 \pm 0.12$ & 3 \\
Growth hormone & & \\
$\quad$ (bovine) $(10 \mu \mathrm{g} / \mathrm{ml})$ & $1.44 \pm 0.07$ & 6 \\
Glucagon $(10 \mu \mathrm{g} / \mathrm{ml})$ & $1.84 \pm 0.17$ & 3 \\
\hline
\end{tabular}

Results are expressed as the ratio of ${ }^{3} \mathrm{H}$-thymidine incorporated relative to that of the control in the same experiment. For reference purposes the ${ }^{3} \mathrm{H}$-thymidine incorporation of all the controls was $12809 \pm 1585 \mathrm{cpm} /$ well

Table 2. Interactions of growth hormone and glucocorticoids on tumour cell growth during an 8-day culture period

\begin{tabular}{lll}
\hline Steroid addition & Control & $\begin{array}{c}\text { + Growth hormone } \\
(10 \mu \mathrm{g} / \mathrm{ml})\end{array}$ \\
\hline $\begin{array}{l}\text { None }(n=6) \\
\text { Prednisolone }\end{array}$ & 1.0 & $1.44 \pm 0.07^{\mathrm{a}}$ \\
$\begin{array}{l}13.5 \mathrm{nmol} / \mathrm{l}(n=3) \\
\begin{array}{l}\text { Dexamethasone } \\
1.2 \mathrm{nmol} / 1(n=3)\end{array}\end{array}$ & $3.96 \pm 0.21$ & $5.15 \pm 0.03^{\mathrm{b}}$ \\
\hline
\end{tabular}

Values are expressed as ratios of ${ }^{3} \mathrm{H}$-thymidine incorporation into cultures with added hormones to that without additions; the number of observations is shown in parentheses.

${ }^{\mathrm{a}} p<0.001 ;{ }^{\mathrm{b}} p<0.02 ;{ }^{\mathrm{c}} p<0.01$ relate to the significant effect of growth hormone addition in each case. The ${ }^{3} \mathrm{H}$-thymidine incorporation into control cultures was: ${ }^{a} 11909 \pm 476 \mathrm{cpm} /$ well; ${ }^{\mathrm{b}} 42616 \pm$ $2252 \mathrm{cpm} /$ well and ${ }^{c} 22470 \pm 395 \mathrm{cpm} /$ well

Table 3. Effects of glucocorticoids on the mass insulin content and growth of cultured cells

\begin{tabular}{lllll}
\hline $\begin{array}{l}\text { Medium } \\
\text { addition }\end{array}$ & $\begin{array}{l}\text { Days } \\
\text { in } \\
\text { culture }\end{array}$ & $\begin{array}{l}\text { DNA } \\
\text { content }\end{array}$ & $\begin{array}{l}\text { Cellular } \\
\text { insulin }\end{array}$ & $\begin{array}{l}{ }^{3} \text { H-thymidine } \\
\text { incorporation }\end{array}$ \\
\hline $\begin{array}{l}\text { Dexamethasone } \\
(0.025 \mathrm{nmol} / 1)\end{array}$ & 12 & $\begin{array}{l}2.9 \pm 0.3^{\mathrm{a}} \\
(n=6)\end{array}$ & $\begin{array}{l}\text { Not } \\
\text { determined }\end{array}$ & $\begin{array}{l}7.3 \pm 0.2^{\mathrm{a}} \\
(n=8)\end{array}$ \\
$\begin{array}{l}\text { Prednisolone } \\
(27000 \mathrm{nmol} / 1)\end{array}$ & 21 & $\begin{array}{l}5.8 \pm 0.1^{\mathrm{a}} \\
(n=5)\end{array}$ & $\begin{array}{l}3.7 \pm 0.5^{\mathrm{a}} \\
(n=7)\end{array}$ & $\begin{array}{l}13.7 \pm 4.0^{\mathrm{a}} \\
(n=7)\end{array}$ \\
\hline
\end{tabular}

Results are expressed as ratios to respective determinations in control cultures without hormones. For 12 days of culture the control values were DNA $0.456 \pm 0.118 \mu \mathrm{g} /$ well and ${ }^{3} \mathrm{H}$-thymidine incorporation $9842 \pm 671 \mathrm{cpm} /$ well. For 21 days of culture the control values were DNA $0.419 \pm 0.015 \mu \mathrm{g} /$ well, insulin $0.725 \pm 0.018 \mathrm{mU} /$ well and ${ }^{3} \mathrm{H}-$ thymidine incorporation $5972 \pm 3454 \mathrm{cpm} /$ well. The number of observations is shown in parentheses. ${ }^{a} p<0.001$ is the significant difference relative to the effect of hormone addition than $1 \%$ of the insulin-positive cells showed mitotic figures.

\section{Effect of different media}

The tumour cells, initially mainly single cells, remained as a suspension culture in medium containing either $5-20 \%$ fetal calf serum or $1 \%$ BSA. The incorporation of tritiated thymidine in seven experiments (number of observations $=49$ ) was shown to be $43 \%$ lower in cells grown in medium containing fetal calf serum compared with cells cultured in medium containing 1\% BSA. The absolute values were $13558 \pm 1238$ and $7731 \pm 647 \mathrm{cpm}$ for medium containing BSA and fetal calf serum respectively on the first day of culture. The difference in ${ }^{3} \mathrm{H}$-thymidine incorporation for tumour cells between the two media was highly significant $(p<0.014$ by the Wilcoxon signed rank test). On day 3 of culture the absolute values were $11544 \pm 1226$ and $6608 \pm 498 \mathrm{cpm}$, respectively $(p<0.002$ by the Wilcoxon signed rank test).

Contaminating fibroblast-like cells proliferated rapidly in fetal calf serum medium but not in BSA medium. Tumour cells in fetal calf serum medium attached to the fibroblast monolayers but were quickly outnumbered and overgrown. Tumour cells cultured in medium containing BSA gradually formed free floating cords and clusters, which made visual counting of cell numbers impossible unless there was prior trypsinisation. Measurements of cell number were more conveniently determined by estimation of DNA content. The initial purified cell suspension prepared for tissue culture contained $>95 \%$ insulin-positive cells by immunohistochemical staining. After $24 \mathrm{~h}$ of culture in BSA medium, $>98 \%$ were positive for insulin and after 4 weeks in BSA-containing medium all cells were positive.

\section{Effect of hormones}

The effects of a wide variety of hormones on tumour cell replication were screened by determining the incorporation of ${ }^{3} \mathrm{H}$-thymidine into cellular DNA (Table 1 ). Triiodothyronine $\left(\mathrm{T}_{3}\right)$, L-thyroxine $\left(\mathrm{T}_{4}\right)$, oestrogens, androgens and glucagon $(1 \mathrm{pg}-100 \mu \mathrm{g} / \mathrm{ml})$ did not markedly affect this parameter. Several glucocorticoids and aldosterone, on the other hand, increased incorporation two- to 12 -fold and were therefore selected for further study. Dose-response experiments with dexamethasone, prednisolone, hydrocortisone and aldosterone produced a stimulatory response related to their potency as glucocorticoids (Fig. 1). The order of potency was dexamethasone $>$ prednisolone $>$ hydrocortisone $\gg$ aldosterone. Bovine growth hormone was tested over a range of $1 \mathrm{pg} / \mathrm{ml}-10 \mu \mathrm{g} / \mathrm{ml}$, but only the highest concentration tested gave a significant increase of radioactive incorporation $(1.44 \pm 0.07$ times the control value; $n=6, p<0.001$ ). This effect continued to be observed when low concentrations of prednisolone $(13.5 \mathrm{nmol} / \mathrm{l})$ 
Table 4. Insulinotropic response of cultured tumour cells

\begin{tabular}{lll}
\hline Duration of culture & \multicolumn{2}{l}{ Culture conditions } \\
\cline { 2 - 3 } & Control & $\begin{array}{c}\text { +Prednisolone } \\
(270 \mathrm{nmol} / 1)\end{array}$ \\
\hline 2 days $(n=3)$ & $2.3 \pm 0.7$ & $2.7 \pm 0.3$ \\
15 days $(n=6)$ & $1.6 \pm 0.5$ & $3.0 \pm 1.0^{\mathrm{b}}$ \\
28 days $(n=3)$ & $1.6 \pm 0.1$ & $2.7 \pm 0.1^{\mathrm{a}}$ \\
\hline
\end{tabular}

Insulin release is expressed as the ratio to the basal secretory rate determined under the same culture conditions. The number of observations is shown in parentheses. The basal insulin release $(U / 1)$ for the control and prednisolone treated cells was respectively: $4.13 \pm 0.52$ and $4.27 \pm 0.82$ (day 2); $0.091 \pm 0.007$ and $0.426 \pm 0.06$ (day 15) and $0.128 \pm 0.013$ and $0.054 \pm 0.003$ (day 28). ${ }^{\mathrm{a}} p<0.001 ;{ }^{\mathrm{b}} p<0.01$ relate to the significant effect of the presence of prednisolone during the culture period

or dexamethasone $(1.2 \mathrm{nmol} / \mathrm{l})$ were also added (Table 2).

Glucocorticoid-supplemented medium supported the division rate of the tumour cells over a prolonged culture period. Cells grown with $0.025 \mathrm{nmol} / 1$ dexamethasone for 12 days and with $27000 \mathrm{nmol} / 1$ prednisolone for 21 days showed an increased DNA content and ${ }^{3} \mathrm{H}$-thymidine incorporation relative to control incubations (Table 3 ). Responses of a similar magnitude were observed to dexamethasone $(0.025 \mathrm{nmol} / 1)$ after 16 days and to a lower concentration of prednisolone $(270 \mathrm{nmol} / 1)$ at 31 days (results not shown).

\section{Effects of tissue culture on insulin content and the insulinotropic response}

The insulin content of cells derived from the fresh tumour was $16 \mathrm{mU} / \mu \mathrm{g}$ DNA. The insulin content of cells cultured with prednisolone for 21 days was $1.12 \mathrm{mU} / \mu \mathrm{g}$ DNA. This value was approximately $60 \%$ that of cells after 21 days of culture in medium containing BSA alone (Table 3). Immunohistochemical staining of such cultures revealed that all cells were positive for insulin.

Fresh tumour cells or tumour cells cultured for 4 weeks with and without addition of prednisolone $(270 \mathrm{mmol} / \mathrm{l}) \mathrm{did}$ not release insulin in response to glucose $(20 \mathrm{nmol} / \mathrm{l})$. A two- to threefold increase in response to leucine $(20 \mathrm{mmol} / \mathrm{l})$ plus theophylline $(5 \mathrm{mmol} / 1)$ however was observed (Table 4$)$. There was no difference between response of cells cultured for 2 days with and without hormone addition. The same stimulus produced a greater relative stimulation of insulin release with cells cultured for 15 or 28 days in medium containing prednisolone $(270 \mathrm{nmol} / 1)$ compared with cells cultured for the same period in BSA medium alone.

\section{Discussion}

The establishment of primary cell cultures is often impeded by the outgrowth of fibroblastic cells. Using cells obtained from the $\beta$-cell tumour this problem was over- come by replacing fetal calf serum with $1 \% \mathrm{BSA}$ in the supplemented culture medium. On the basis of ${ }^{3} \mathrm{H}$ thymidine uptake and immunohistochemical analysis, the medium containing BSA permitted proliferation of the $\beta$-cells even better than fetal calf serum-containing medium during the first few days. Subsequent introduction of fetal calf serum did not enhance growth (data not shown). Glucocorticoid addition resulted in stimulated ${ }^{3} \mathrm{H}$-thymidine incorporation and increased DNA content relative to cultures in BSA medium alone, but did not alter the cellular composition $(98 \% \beta$ cells). It was therefore concluded that the increased division of $\beta$ cells was promoted by these hormones. We are currently investigating whether these effects persist in cultures over periods greater than 31 days.

This phenomenon may be a mirror of the hyperplastic changes in normal islets which have been observed in animals treated with glucocorticoids or growth hormone [12-14]. However, it is not known whether the effects observed in vivo are direct or whether they may be modulated through the resulting hyperglycaemia [1, 4-6]. The literature concerning the effects of glucocorticoids on $\beta$ cells in culture is conflicting, possibly due to the different experimental conditions used and the different stages of tissue development at which studies have been carried out [15-20].

Fong et al., using a cloned cell line derived from the tumour used in the present studies [21], found no increase in cell numbers when hydrocortisone $\left(10^{-7} \mathrm{~mol} / \mathrm{l}\right)$ was added [22]. These authors, however, did observe a growth-promoting effect of insulin at a concentration greater than $30 \mathrm{ng} / \mathrm{ml}$, consistent with data from other cell types [23, 24]. In our experiments, endogenous insulin contributed more than $50 \mathrm{ng} / \mathrm{ml}$ to the medium in all cases. There would appear to be a difference between the mitogenic response of primary cell cultures studied here and that of permanent cell lines derived by extensive selection. Since the insulin content in the parent tumour is more than 100-fold that of the derived cell lines, differences in the degree of differentiation or gene expression could account also for differences in hormone responsiveness.

The primary cell culture described here released insulin in response to the same stimuli as the parent tumour and moreover remained tumorigenic when injected back into host animals (results not shown). These findings indicate the differentiated character of the cells. It is hoped that these studies will contribute to understanding the factors necessary to establish long-term cultures of islet-derived tissues and may suggest variables which can be examined in non-transformed islets.

Acknowledgements. This work was supported by a grant from the British Diabetic Association. G.B. was supported by a grant from the Beamglow Research Fund to Mr. P. McMaster to whom we are also grateful for encouragement. We are also indebted to Dr. J.C. Hutton for his valuable help, advice and discussion and to Dr. R. M. Merion for help with the statistical analysis. We thank Mrs. L.Creswell and Miss A. Jones for their excellent secretarial assistance. 


\section{References}

1. Wasielewski E, Chick WL (eds) (1977) Pancreatic $\beta$-cell culture. In: Proceedings of the 5th Workshop Conference, Hoechst, Kitzbuhel, 5-9 October 1976. Excerpta Medica, Amsterdam, Oxford

2. Andersson A (1975) Synthesis of DNA in isolated pancreatic islets maintained in tissue culture. Endocrinology 96: 1051-1054

3. Like AA, Chick WL (1969) Mitotic division in pancreatic beta cells. Science 163: 941-943

4. Chick WL, Lauris V, Flewelling JH, Andrews KA, Woodruff JM (1973) Effects of glucose on beta cells in pancreatic monolayer cultures. Endocrinology 92: 212-215

5. King DL, Chick WL (1976) Pancreatic beta cell replication. Effects of hexose sugars. Endocrinology 99: 1000-1009

6. de Gasparo M, Milner GR, Norris PD, Milner RDG (1978) Effect of glucose and amino acids on fetal rat pancreatic growth and insulin secretion in vitro. J Endocrinol $77: 241-248$

7. Chick WL, Warren Sh, Chute RN, Like AA, Lauris V, Kitchen KC (1977) A transplantable insulinoma in the rat. Proc Natl Acad Sci USA 74: 628-632

8. Sopwith AM, Hutton JC, Naber SP, Chick WL, Hales CN (1981) Insulin secretion by a transplantable rat islet cell tumour. Diabetologia 21: 224-229

9. Kissane JM, Robins EG (1958) The fluorometric measurements of deoxyribonucleic acids in animal tissues with special reference to the central nervous system. J Biol Chem Vol 233: 184-188

10. Hales CN, Randle PJ (1963) Immunoassay of insulin with insulinantibody precipitate. Biochem J 88: 137-146

11. Heyderman E (1979) Immunoperoxidase technique in histopathology: applications, methods and controls. J Clin Pathol 32: 971-978

12. Campbell J, Rastogi KS, Hausler HR (1966) Hyperinsulinemia with diabetes induced by cortisone and the influence of growth hormone in the Chinese hamster. Endocrinology 79:749-756

13. Like AA, Chick WL (1974) Pancreatic beta cell replication induced by glucocorticoid in sub-human primates. Am J Pathol 75: 329-348

14. Kern H, Logotheotopoulos $\mathbf{J}$ (1970) Steroid diabetes in the guinea pig. Diabetes 19:145-154

15. Brundstedt $\mathbf{J}$, Nielsen JH (1981) Direct long-term effect of hydro- cortisone on insulin and glucagon release from mouse pancreatic islets in tissue culture. Acta Endocrinol 96: 498-504

16. Chick WL (1973) Beta cell replication in rat pancreatic monolayer cultures. Effects of glucose, tolbutamine, glucocorticoids, growth hormone, glucagon. Diabetes 22: 687-693

17. McEvoy RC, Hegre OD (1976) Fetal rat pancreas in organ culture. Effects of media supplementation with various steroid hormones on the acinar and islet components. Differentiation 6:105-111

18. McEvoy RC, Hegre OD, Lazarow A (1976) Fetal rat pancreas in organ culture. Effect of corticosterone concentrations on the acinar and islet cell components. Differentiation $6: 17-26$

19. McEvoy R (1980) Fetal and neonatal rat pancreas in organ culture: Age related effects of corticosterone on the development of the islet cells. Am J Anat 157: 319-327

20. McEvoy RC, Leung PE, Goggius JA (1981) Tissue culture of fetal rat islets: corticosterone promotes D-cell maintenance and function. Endocrinology 108: 2277-2282

21. Gazdar AF, Chick WL, Oie HK, Sims HL, King DL, Weir GC, Lauris V (1980) Continuous clonal insulin and somatostatin secreting cell lines established from a transplantable rat islet cell tumour. Proc Natl Acad Sci USA 77: 3519-3523

22. Fong HKW, Chick WL, Sato GH (1981) Hormones and factors that stimulate growth of a rat islet tumour cell line in serum-free medium. Diabetes 30: 1022-1028

23. Rabinovitch A, Russell Th, Patels Y, Mintz D (1982) Insulin and MSA (an insulin growth factor) in neonatal rat pancreatic monolayer cultures. Diabetes 31: 160-164

24. Hayashi J, Larner J, Sato G (1978) Hormonal growth control of cells in culture. In Vitro 14: 23-30

Received: 25 March 1983

and in revised form: 17 August 1984

G. Brons

Department of Surgery

University of Cambridge

Addenbrooke's Hospital

Cambridge CB2 2QQ

UK 